\section{Tariene Wilcocks}

Ms. Tariene Wilcocks, Parttime Lecturer, Department of Architecture, Tshwane University of Technology, No 201 Fairfield, 1164 Dormer Avenue, Queenswood, South Africa. Phone: + 2763 695 4584, email: <wilcockst@ tut.ac.za>

\section{Jacques Laubscher}

Prof. Jacques Laubscher, Head of Department, Department of Architecture, Tshwane University of Technology, PO Box 95469 , Waterkloof, 0145, South Africa. Phone: + 2712382 5252,

email: <laubscherj@tut.ac.za>

DOI: http://dx.doi.

org/10.18820/24150487/

as $24 \mathrm{i} 2.6$

ISSN: 1023-0564

e-ISSN: 2415-0487

Acta Structilia 2017 24(2):

146-167

(c) UV/UFS

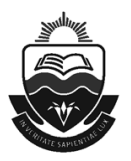

Investigating alternative dispute resolution methods and the implementation thereof by architectural professionals in South Africa

Peer reviewed and revised

\begin{abstract}
Given the number of role players and the complexity of the building process, disputes are inevitable. As an alternative to litigation, which is often costly and time consuming, Alternative Dispute Resolution (ADR) methods could be used. Arbitration, mediation, negotiation and adjudication are a few examples of ADR and, if understood correctly and implemented effectively, ADR could prove beneficial to all parties involved in disputes.
\end{abstract}

This article investigates the current knowledge, implementation and benefits of ADR within the South African built environment. The focus population of the study is architectural professionals, as defined by the South African Council for the Architectural Profession (SACAP). A questionnaire was distributed among 581 architectural professionals to determine how informed these architectural professionals are about the different ADR methods, their implementation and resultant consequences.

The real-world problem is that architectural professionals do not apply ADR methods because of the lack of knowledge regarding the implementation and benefits of ADR. It is considered that the unique contribution of this article lies in the fact that all architectural professionals in South Africa were asked to participate in the survey regarding ADR, its methods, implementations, and their knowledge thereof. This is the first evidence of many anecdotal statements made on the lack of implementation and knowledge regarding ADR methods within the architectural profession of South Africa. The findings reveal that the 
majority of the respondents are not familiar with the term ADR and could not provide a clear definition; $69.4 \%$ of architectural professionals do not discuss ADR methods with their client before entering into an agreement, and $58.4 \%$ of the population have hardly any or no knowledge regarding the methods and benefits of ADR.

These observations indicate that a significant portion of architectural professionals are currently in breach of the SACAP Code of Conduct and could potentially lose their professional license. These results indicate a possible way forward to facilitate a larger implementation of ADR in future building projects.

Keywords: South African Council for the Architectural Profession (SACAP), alternative dispute resolution (ADR), litigation.

\begin{abstract}
Abstrak
Gegewe die aantal rolspelers en kompleksiteit van die konstruksiebedryf is dispute onvermydelik. As 'n alternatief tot litigasie, wat soms duur sowel as tydrowend kan wees, kan alternatiewe geskilbeslegtingsprosedures (ADR) gebruik word. Arbitrasie, bemiddeling/mediasie, onderhandeling en beoordeling is ' $n$ paar voorbeelde van alternatiewe prosedures en, as dit korrek verstaan en geïmplementeer word, kan dit voordelig wees vir alle partye betrokke in die dispuut.

Die studie ondersoek die huidige kennis, implementering en voordele van ADR. Die populasie vir die studie is gefokus op professionele persone in die boukunde, soos beskryf deur die Suid-Afrikaanse Raad vir die Argitektuurprofessie (SACAP). ' $\mathrm{n}$ Vraelys is versprei na 581 boukundiges om vas te stel wat boukundiges in die bedryf se huidige kennis is rakende die verskillende ADR-metodes, die implementering daarvan en die bypassende gevolge.

Die werklike probleem is dat boukundiges nie die ADR-metodes toepas nie, weens die gebrek aan kennis rakende die implementering en voordele van ADR. Die unieke bydrae van hierdie artikel lê in die feit dat alle boukundiges in Suid Afrika gevra is om a an die opname oor ADR, metodes, implementering en hul kennis daarvan deel te neem. Dit is die eerste bewys van baie anekdotiese stellings oor die gebrek aan implementering en kennis aangaande ADRmetodes in die boukunde van Suid Afrika. Die resultate bewys dat die meerderheid boukundiges nie vertroud is met die term ADR nie en dus ook nie 'n duidelike definisie daarvan kan gee nie; $69.4 \%$ van die boukundiges bespreek nie ADR-metodes met hul kliënte voordat hulle 'n ooreenkoms teken nie. Daar is ook bewys dat $58.4 \%$ van die boukundiges min of geen kennis van die metodes en hul bypassende voordele het nie.

Hierdie waarnemings dui daarop dat 'n merkwaardige hoeveelheid boukundiges huidiglik die SACAP-gedragskode oortree en dat hul professionele lisensies potensieel weggeneem kan word. Die resultate dui ook daarop dat daar 'n moontlike pad vorentoe is om ' $n$ groter implementering van ADR in toekomstige bouprojekte te fasiliteer.
\end{abstract}

Sleutelwoorde: Suid-Afrikaanse Raad vir die Argitektuurprofessie (SACAP), alternatiewe geskilbeslegtingsprosedures (ADR), litigasie. 


\section{Introduction}

Chapter 2 of the Constitution of the Republic of South Africa makes provision for ADR in Section 34 (South Africa, 1996: 14). It grants parties the right to have a dispute resolved by means of a public hearing as an alternative to legal proceedings. Arbitration, mediation, negotiation and adjudication are some of the alternative methods that can be used when resolving disputes in South Africa. This is, therefore, also applicable to the construction industry. ADR has a variety of important attributes, including cost effectiveness, time saving, confidentiality, privacy, and the preservation of business relationships. If both parties agree to the method of procedure, the process of ADR could be entered into on a voluntary basis (WIPO, 2012: 5). The complex and specialised nature of construction projects contributes to disputes arising between two parties (Maritz, 2007: 78). According to Bvumbwe and Thwala (2011:35) and Botha (2000: 1), the major causes of disputes are the following:

- Use of improperly or poorly drafted contracts;

- Financial issues and claims;

- Poor communication from client and contractor;

- Poor management - time, funds and programme, and

- Emotions - the ability to handle stress.

This article is limited to the built environment professional's knowledge regarding the implementation and benefits of ADR methods, with specific focus on architectural professionals in South Africa. The Architectural Profession Act 44 of 2000 states that all registered persons are obligated to comply with the SACAP Code of Conduct (Board Notice 154 of 2009). Among others, Board Notice 154 of 2009 states that all architectural professionals should enter into professional service agreements that provide for dispute resolution. It is cause for concern that architectural professionals in South Africa often overlook the necessity of professional service agreements that make provision for ADR, despite the obvious risks involved. As a result, these professionals have no recourse for dispute resolution, should it be required.

In 2008, the South African Institute of Architects (SAIA) published a professional service agreement titled the SAIA Client-Architect Agreement (SAIA CAA 2008). This agreement makes provision for mediation and arbitration when disagreements arise during the construction process. Despite its availability, a large number of architectural professionals still do not make use of the SAIA CAA 2008. In a study, Pelser (2013: 36) concluded that, for architectural projects, 
the SAIA CAA 2008 was only used in 3\% of construction projects documentation in Pretoria over the past five years. One of the reasons for this is architectural professionals' general lack of knowledge concerning the content of such agreements. It could be argued that a greater awareness of ADR by architectural professionals could benefit all those involved in the building process. However, the lack of understanding of professional service agreements has a direct impact on the implementation of ADR.

It is, therefore, important to investigate the use and knowledge of ADR in the built environment of South Africa by introducing the origin of ADR and how it relates to the built environment; collecting and analysing data from architectural professionals on the knowledge, implementations, consequences and benefits of ADR, in order to inform architectural professionals on appropriate ADR methods and the importance of the implementation thereof.

This article aims to determine

- the extent of the knowledge and implementation of architectural professionals on ADR;

- $\quad$ whether architectural professionals discuss ADR with their clients prior to the commencement of a project, and

- whether architectural professionals are informed about the different methods and benefits of ADR.

\section{A brief history of ADR}

This article presents a brief historical overview of the origins of ADR in the South African legal system as well as its relevance to the built environment. When faced with a dispute, built environment professionals could use this literature to obtain pertinent information on ADR methods, implementations as well as some advantages and disadvantages of the different methods. The literature review also serves as a background to the study.

\subsection{Origin of ADR in the South African legal system}

During the 1980s, ADR was used increasingly in the United States (US) in an attempt to resolve court backlogs. Subsequently, different forms of ADR evolved to suit specific needs in different sectors (Freyer, 1997: 108).

In South Africa, the existence of informal methods of ADR can be traced back to the 1960s, when traditional African communities had disputes over food, land and partners (Barrett \& Barrett, 2004: 10). 
These disputes were often brought before a traditional leader during a meeting of the community. This method of resolving disputes is closely associated with adjudication, mediation or arbitration.

In South Africa, arbitration is governed by the Arbitration Act 42 of 1965. This Act provides citizens with legal rights to have disputes settled by arbitration tribunals (Ntuli, 2013: 9). This Act applies to domestic and international arbitration proceedings and is of the opinion that foreign arbitration awards are accepted in South Africa. When parties agree to submit any dispute arising out of the contract, the dispute has to be referred to one of the official arbitration bodies in South Africa. There are four main arbitration bodies in South Africa:

- The Arbitration Foundation of South Africa (AFSA);

- The Association of Arbitrators (Southern Africa) (AOA);

- The Commission for Conciliation, Mediation and Arbitration (CCMA), and

- $\quad$ Africa Alternative Dispute Resolution (AADR).

Disputes occur in all facets of life. ADR is rapidly expanding into all sectors of the economy, including divorce and child custody, educational settings, as well as commercial, engineering and construction disputes (Trollip, 1991: 8). As some of these disputes are complex in nature and involve large amounts of money, ADR can assist the parties involved to settle, or narrow down the issues of the dispute. It is also beneficial to parties with personal or business relationships that require confidentiality to favour early settlement in order to achieve a positive solution for all involved.

The use of ADR methods has established a mechanism to avoid formal court litigation and is expected to have a positive outcome. However, ADR holds many challenges and has not yet been fully embraced by professionals in the South African built environment (De Oliveira, 2012: 80). It is evident that awareness should be created to ensure that ADR becomes an essential part of the legal system of South Africa.

\subsection{ADR in the South African built environment}

The built environment of South Africa has developed the process of ADR over a period of three decades, when Quail (1978: 165) established the introduction of the mediation process in 1976. The built environment of South Africa is a large industry that brings together a variety of different professionals. Verster (2006: 13) states that the built environment should address the possible risk of disputes that have an impact on the time and cost of building projects. It 
Wilcocks \& Laubscher • Investigating alternative dispute-resolution ...

has been reported that problems associated with payments have affected the supply chain of the construction industry and negatively impacted on the contracting environment (Maritz, 2007: 419).

In the construction industry, disputes are a common occurrence and affect the growth and performance of the built environment (Thumbiran, 2015: 1). Consequently, it is necessary to examine traditional means of resolving disputes, as litigation is too costly and time consuming. The development and implementation of ADR methods often increase with accelerated rates of construction, design and procurement documents (Finsen, 2005: 214-216). Finsen (2005: 216) and Verster (2006: 17) argue that ADR is an essential part of the management of construction projects and plays a fundamental role in the successful completion of these complex projects, although it is not implemented throughout the South African construction industry. There are many other sectors in the economy where ADR is expanding rapidly, providing parties with positive solutions to disputes. The ADR Network South Africa is one of many agencies providing assistance in ADR to both the public and the private sectors. However, there is a major need for appropriate resources and awareness regarding ADR methods specific to the built environment of South Africa.

As mentioned earlier, the construction industry is known for its complex nature; it must, therefore, provide an expert facilitator to settle disputes. According to Povey (2005: 2), the facilitator may be a currently practising professional with the necessary experience, or a retired professional in the industry. Facilitators must also be registered with the AOA. Verster $(2006: 17)$ suggests that ADR methods should be applied more effectively, resulting in more time being allocated to productively manage the project. It is necessary to understand that new procedures, methods and increased awareness may be vital, in order to expand the fast-track nature of the construction industry.

\section{ADR methods commonly used in the built environment}

Since the late 1980s, standard forms of ADR have evolved, each with their own characteristics, as a result of a search for quicker and cheaper alternatives to litigation (Chong \& Zin, 2012: 433). According to Motiwal (1998: 117), ADR techniques have been developed by leading universities and ADR centres in the US, Great Britain, Canada and Australia. In support of this statement, Paul Pretorius, advocate and editor of Dispute Resolution 1993, undertook two study tours in the US, in order to learn about alternate forms of dispute resolution. 
Pretorius (1990: 39) concluded that as far as the US is concerned, significant academic resources have been devoted to the scientific study of conflict and the development of appropriate institutions and practices to establish appropriate ADR methods. A study conducted by Van Zyl, Verster \& Ramabodu (2010: 521) revealed that the following are the most preferred ADR methods in South Africa's built environment: negotiation, conciliation, mediation, adjudication, and arbitration.

\subsection{Negotiation}

Negotiation is one of the most commonly used ADR methods for resolving disputes, because it is an informal method used as a preventative measure to avoid fully fledged disputes between parties (Chong \& Zin, 2012: 430). Fisher, Ury \& Patton (1991: 6) define negotiation as "a basic means of getting what you want from others". It is a process whereby parties attempt to reach a settlement without involving an independent third party (Ramsden, 2009: 2). Negotiation is convenient, unstructured and often preserves working relationships.

The simplest way of settling disputes is by means of negotiation, because the parties themselves are in the best position to know the strengths and weaknesses of their own cases (Wang, 2000: 191). However, negotiation does not always guarantee success when attempting to settle disputes between parties. According to Pretorius (1993: 38), this may be caused by a general lack of knowledge, in conjunction with parties being too subjective and emotionally involved to make rational decisions.

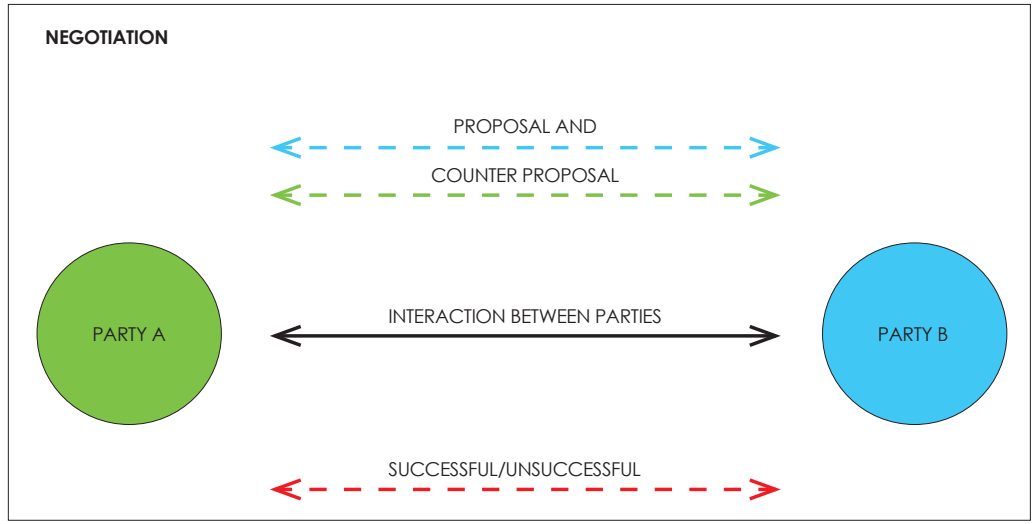

Figure 1: Summarised illustration of negotiation

Source: Wilcocks, 2017: 22 
Wilcocks \& Laubscher • Investigating alternative dispute-resolution ...

\subsection{Mediation}

Mediation is an ADR method in which a neutral third party, known as the mediator, seeks to resolve a dispute between the parties in conflict (Chong \& Zin, 2012: 430). According to Goldberg, Sander and Rogers (1992: 103), "mediation is an assisted and facilitated negotiation carried out by a third party". Mediation is also used in other sectors of the economy, namely commercial, civil, labour, family, interpersonal, community, complex public disputes, environmental cases and a wide range of other disputes (Brown \& Marriot, 1993: 291).

Mediation proceedings may only take place if the parties are in agreement and willing to assist in reaching a settlement. If a settlement is reached, the mediator will provide the parties with a written agreement that will become legally binding once it has been signed by both parties (Ramsden, 2009: 3). Chong and Zin (2012: 40) and Bollen, Euwema \& Muller (2010: 420) argue that the success of mediation depends on its fairness, simultaneously with the cooperation of both parties during the mediation.

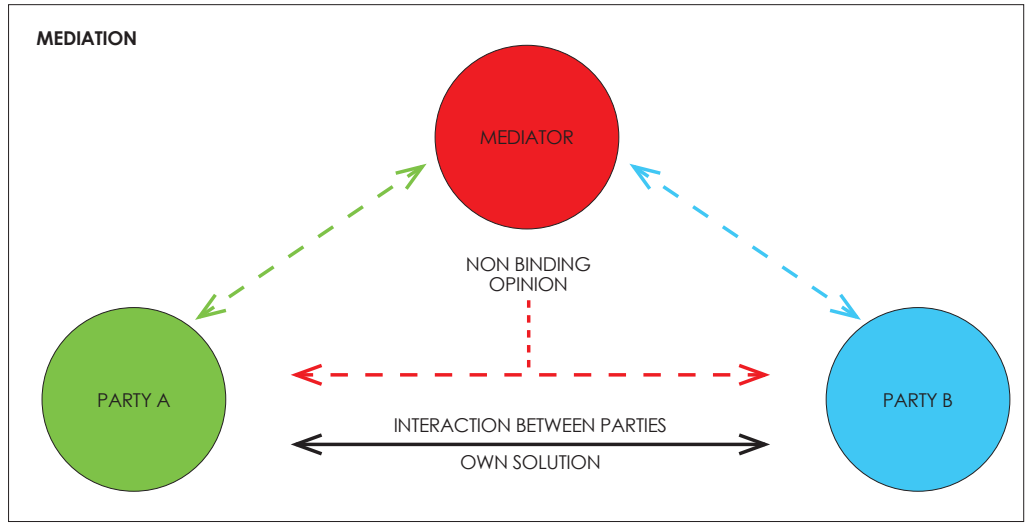

Figure 2: Summarised illustration of mediation

Source: Wilcocks, 2017: 23

\subsection{Conciliation}

Conciliation is a process that is voluntarily entered into by the disputing parties; it involves an impartial third party. According to Stewart (2006: online), conciliation is "a settlement out of court, usually by the assistance of a neutral third party". Loots (1991: 1012) further states that the method of conciliation is flexible and that the 
outcome of the dispute is entirely dependent on the willingness of the parties to participate.

Previous parties have stated that their favoured method of ADR is either mediation or conciliation. These methods are often more effective in resolving disputes than litigation, because the outcome of disputes is interest based for both parties rather than rights based and the process of conciliation is not as prolonged and costly as the process of litigation (Rao, 2009: 320).

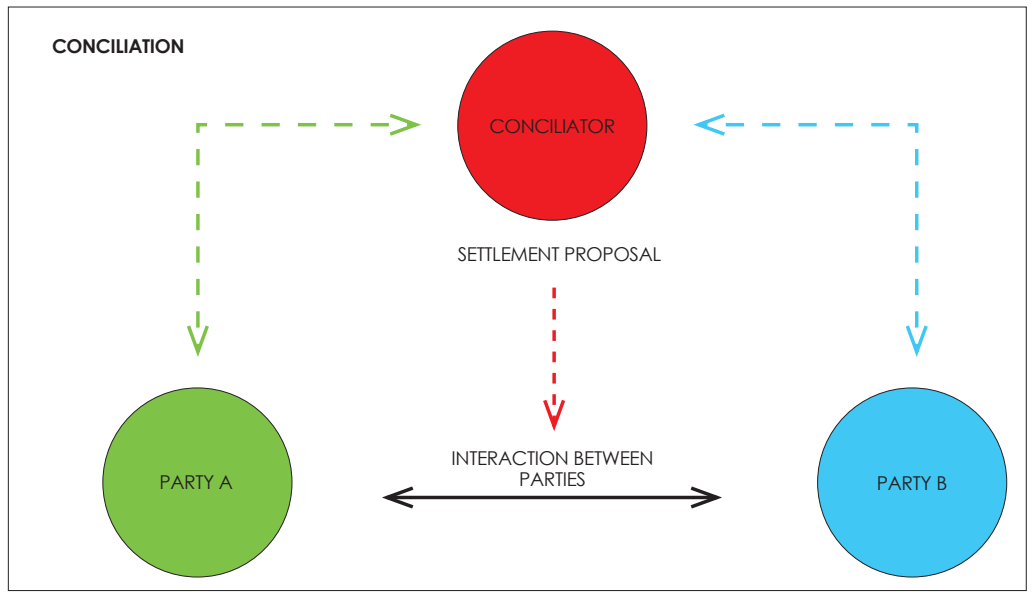

Figure 3: Summarised illustration of conciliation

Source: Wilcocks, 2017: 25

\subsection{Adjudication}

The OED (2016: 16) states that the generally accepted definition of adjudication is as follows: "the process of making an official decision about who is right in a disagreement between two groups or organisations". According to Hibberd and Newman (2001), the process of adjudication is an accelerated form of ADR whereby a neutral or independent third party makes a binding determination on the dispute, unless it is overturned by an arbitrator.

However, the parties involved may not proceed with arbitration or litigation until 28 days after the adjudicator has made the determination. This method of ADR is less disruptive, as parties can continue with construction work and meet their obligations. Adjudication is an ADR method that allows for business relationships to continue while parties resolve their disputes. 
Wilcocks \& Laubscher • Investigating alternative dispute-resolution ...

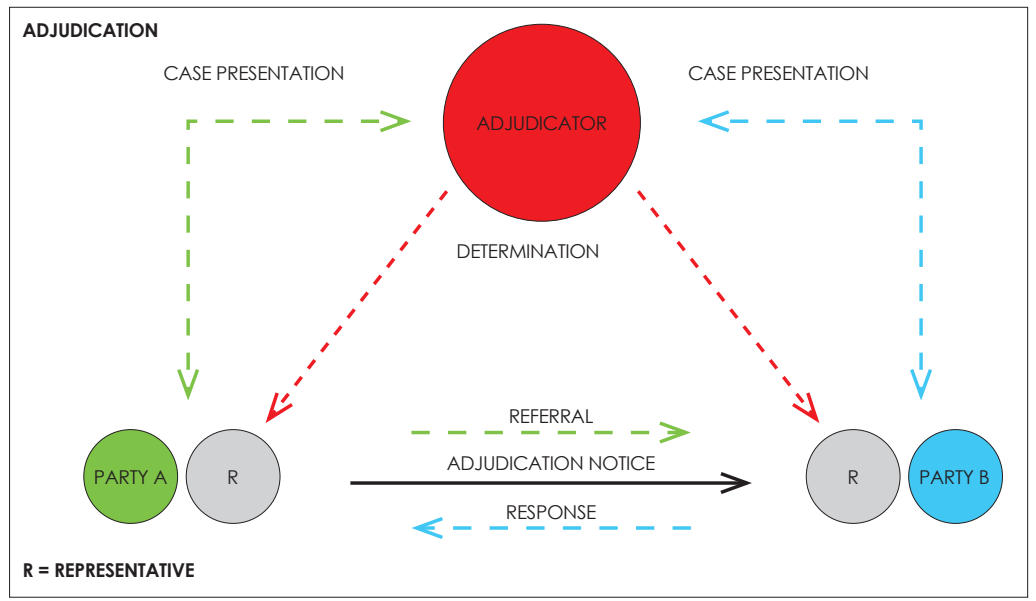

Figure 4: Summarised illustration of adjudication

Source: Wilcocks, 2017:26

\subsection{Arbitration}

Arbitration is considered to be one of the most common methods of ADR in the built environment. Arbitration can be defined as "a judicial and more formal process where the disputing parties present their cases to an independent third party of their choice, known as the arbitrator" (Pretorius, 1993: 5). This method was known to the Romans, used by the Dutch and English during the period of colonial expansion, and extensively used in the construction industry (Finsen, 1999: 203-204).

The process of arbitration is similar to court procedure and may be associated with a formal trial. However, it can be more informal and relaxed, as it can be modified by the agreed parties. Brown and Marriot (1993: 288) state that arbitration is a suitable method of ADR, because a neutral third party with highly specialised knowledge on the subject matter makes a final and binding award, unlike other ADR methods. 


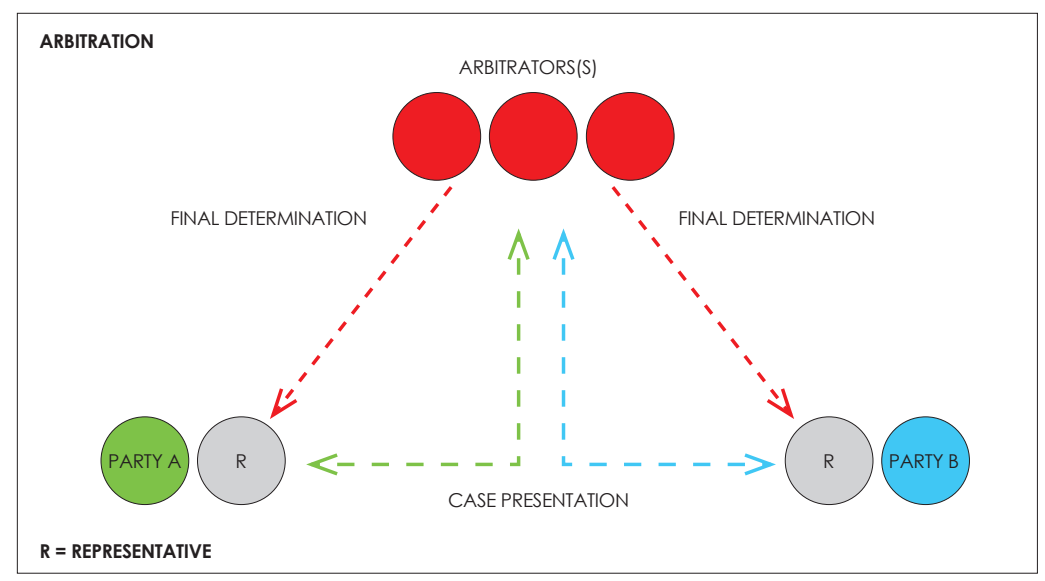

Figure 5: Summarised illustration of arbitration

Source: Wilcocks, 2017: 27

\section{Methodology}

The study used a quantitative research approach, as the research involves numbers and measurement (data to be collected), thus emphasising frequencies and statistics (expressed in numbers) (Struwig \& Stead, 2001: 7; Leedy \& Ormrod, 2005: 179). Because the study focuses on information-seeking behaviour around the current knowledge that architectural professionals have regarding ADR and the implementation thereof, as provided for by the SAIA CAA 2008, a survey research method would be the most appropriate for this study (Courtright 2007: 273).

Williams (2007: 67) classifies a survey as a standard quantitative research method. Survey research involves acquiring information about one or more groups of people, perhaps about their opinions, characteristics, attitudes, or previous experiences, by asking questions and tabulating the answers. The ultimate goal is to learn about a large population by surveying a sample thereof (Leedy \& Ormrod, 2005: 183). Survey instruments can be broadly classified into two categories, namely questionnaires and interviews (Boubala, 2010: 55). This study used structured questionnaires to collect and analyse data obtained from architectural professionals in South Africa. 
Wilcocks \& Laubscher • Investigating alternative dispute-resolution ...

\subsection{Data collection}

The questionnaire contained 17 main questions on whether architectural professionals implement ADR; discuss ADR prior to entering into an agreement with a client, and whether architectural professionals are informed about the different methods and benefits of ADR. The questionnaire was designed to test the individual experience and understanding of professionals on the current knowledge, implementations, consequences, and benefits of ADR.

The questionnaire was used as a survey method, with two datacollection options. These data-collection methods were chosen to collect data from as many participants as possible. An online questionnaire, created using SurveyMonkey, was emailed to the specific target audience. This is a popular web-based survey software that provides for data collection, data analysis and brand management (SurveyMonkey, 2016).

The second data-collection method is in hardcopy format. This was made available to professionals who found the online survey method impractical, or did not have access to the internet or email. The hardcopies were distributed where necessary, in order to reach as many participants as possible. The questionnaire addresses the relevant research questions developed by the researcher, in order to establish the current knowledge on ADR.

\subsection{Design of the questionnaire}

The questionnaire was aligned with the specific research subproblems:

- Subproblem 1 - Are architectural professionals familiar with, and well informed about ADR?

- $\quad$ Subproblem 2 - Do architectural professionals discuss ADR prior to entering into an agreement with a client or only once disputes arise?

- Subproblem 3 - Are architectural professionals informed about the different methods and benefits of ADR?

The questionnaire was also discussed with the study leader, an independent statistician and an architectural practice specialist to ensure that the information stated in the questionnaire is relevant and meaningful. The questionnaire is divided into three sections:

Section A: General Information

This section covers the participants' personal information as well as background on their education and category of SACAP registration. 
Section B: Alternative Dispute Resolution (ADR)

This section addresses subproblems 1, 2 and 3, by establishing the knowledge and implementation of ADR by architectural professionals in South Africa. The researcher also aims to determine whether architectural professionals discuss ADR prior to entering into an agreement with a client and whether architectural professionals are informed about the different methods and benefits of ADR.

Section C: The South African Institute of Architects (SAIA)

This section focuses on the basic knowledge that architectural professionals have regarding the methods and benefits of $A D R$, as specifically provided for in the SAIA CAA 2008.

The initial questionnaire was pre-tested by circulating it to 10 registered members of SACAP who formed part of the target population. The objective of the pre-test was to determine any uncertainty and/or errors. It also served as a testing mechanism to ensure that all of the subproblems were addressed effectively. This exercise also confirmed the estimated time required to complete the questionnaire. These questionnaires do not form part of the data for the main study, because they were only used to develop the questionnaire.

\subsection{Sampling size and its level of presentation of the population}

The SAIA agreed to make their database of contacts available. However, this had an impact on the representativity of the data, as SAIA is mainly focused on architects, not on all architectural professionals. Therefore, the researcher approached SACAP to ensure that all architectural professionals in South Africa were reached (13 622 members).

The sampling size was determined by the number of registered SACAP members in South Africa. The 2014/2015 annual SACAP report listed 10525 registered members in South Africa (SACAP, 2015: 27). However, SACAP agreed to assist the researcher with the study and later informed the researcher that the survey was sent out to 13622 professionals (Van Stade \& Chiunda, 2016). SACAP distributed the questionnaire with only the contact details of the researcher and the supervisor, without placing other limitations on its 13622 members. The sampling size was ultimately defined by the reality that all the architectural professionals in South Africa were reached.

The survey response from the sampling size totalled 581 participating architectural professionals. Krejcie and Morgan (1970: 608) recommend that, for general research activities in the 
Wilcocks \& Laubscher • Investigating alternative dispute-resolution ...

construction-related professionals, a sample size of 370 is valid for a population of 15000 . This recommendation validates the sample size of 581 as efficient for a population of 13622 .

The 581 participants represent $4.27 \%$ of the registered architectural professionals. Of the 581 responding participants, 396 completed Section A and B of the questionnaire, consequently representing $2.91 \%$ of the architectural population in South Africa. In total, the questionnaire was fully completed by 346 out of 581 research participants who, at the time of undertaking the research, represent $2.55 \%$ of registered SACAP members in South Africa.

\subsection{Data analysis and interpretation of findings}

Biographical information on the research participants was required, in order to draw conclusions regarding the age and gender groups that might prefer to use ADR. This could also determine whether or not a participant's level of education impacts on the use of ADR.

The questionnaire also made use of three different categories of a 5-point Likert scale, in order to obtain and analyse the respondents' opinions. Likert-type or frequency scales use fixed choice response formats and are designed to measure attitudes or opinions (Bowling, 1997; Burns \& Grove, 1997). For the purpose of analysis and interpretation, the relevant categories of Likert scales were measured by occurrences, agreement and content. Occurrences is measured where 1 is never ( $10 \%$ of times), 2 rarely ( $25 \%$ of times), 3 sometimes (50\% of times), 4 mostly (75\% of times), and 5 always (100\% of times). Agreement is measured where 1 is strongly disagree, 2 disagree, 3 don't know, 4 agree, and 5 strongly agree. Content is measured where 1 is never heard of it, 2 seen it before, 3 read it, 4 know most of it, and 5 know all of it. By using the various Likert scales, the researcher was able to analyse the respondents' opinions, knowledge and implementation.

The researcher obtained the raw data from the online platform SurveyMonkey, upon which the findings were reviewed against the foregoing literature review. The data was then processed using the Microsoft Excel ${ }^{\circledR}$ (Microsoft Office ${ }^{\circledR}$ suite 2007) software program, in order to present statistical graphics.

\subsection{Comparative data}

The researcher grouped certain categories of possible answers together, using the online platform SurveyMonkey. This enabled the researcher to test the statistical significance from respondents, 
regarding age, gender, qualification and category of SACAP registration. These categories are presented in Table 1.

Table 1: Grouping of various categories

\begin{tabular}{|l|l|}
\hline \multirow{2}{*}{ Age } & $25-45$ years \\
\cline { 2 - 2 } & $46+$ \\
\hline \multirow{2}{*}{ Gender } & Male \\
\cline { 2 - 2 } & Female \\
\hline \multirow{2}{*}{ Qualification } & Degree (Bachelors or Masters) \\
\cline { 2 - 2 } & No degree \\
\hline \multirow{2}{*}{ SACAP category of registration } & Professional architect \\
\cline { 2 - 2 } & Professional (Senior) architectural technologist \\
\hline
\end{tabular}

The comparative data will identify the relationship between various questions. The findings of the data might also identify possible gaps and problems within the profession. The comparative data will only make use of simplified answers by viewing strongly agree and agree as one, and strongly disagree and disagree as one.

Although it is not the main aim of this study, the link between gender and/or age (with a resultant level of experience) and the implementation of ADR are questioned. Should correlations become evident, shortcomings could possibly be addressed through mentorship programmes and Continuing Professional Development (CPD) programmes.

\section{Findings}

The researcher analysed and interpreted the data gathered from the participants by graphically summarising each question individually, in order to formulate preliminary findings and subsequently proffer recommendations and conclusions.

In this article, the major findings are addressed according to the specific subproblems and summarised graphically to assist the reader on the significant parts of the study.

\section{$5.1 \quad$ Results}

The following bar graph indicates the summarised results of architectural professionals in South Africa on the implementation, knowledge, benefits and methods of ADR as well as whether ADR is discussed prior to entering into an agreement with a client. This 
will mainly represent the overall knowledge of, and implementation of ADR methods by architectural professionals in South Africa. This is followed by explaining each subproblem and its relevant results.

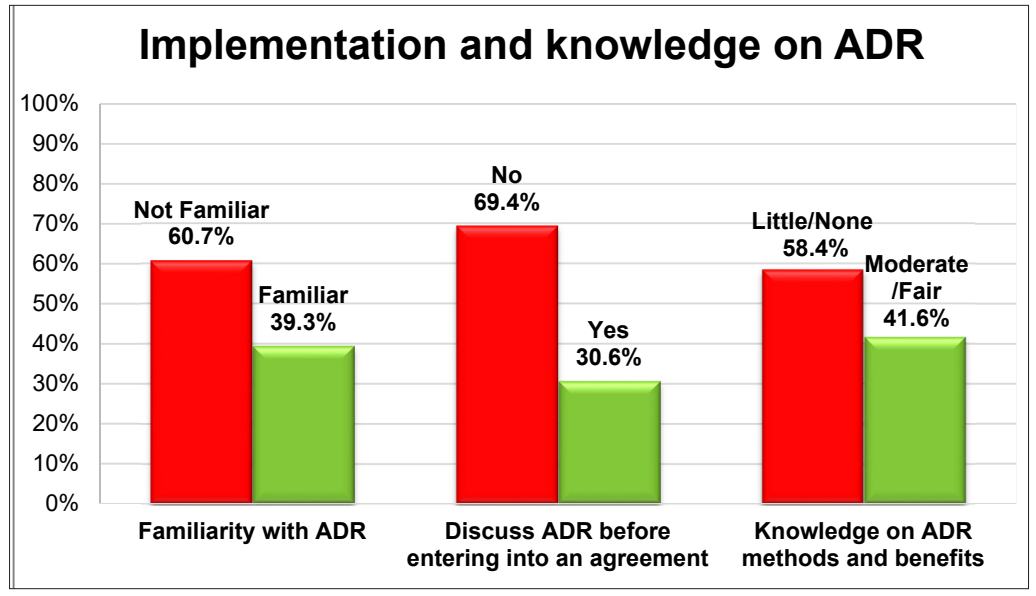

Figure 6: Graphic summary of the implementation and knowledge regarding ADR in the SAIA CAA 2008

\subsection{Subproblem 1}

Are architectural professionals familiar with, and well informed about ADR?

Research revealed that the majority of the respondents are not familiar with the term ADR and could not provide a clear definition. Only $39.3 \%$ of the population is familiar with ADR. This suggests that if the majority of the target population does not have appropriate knowledge on this topic, they most definitely do not implement ADR.

The research indicates that the current lack of knowledge on ADR is cause for concern, considering that the built environment is often faced with disputes arising between the professional and the client. The researcher is able to conclude that, due to the lack of knowledge, a large number of professionals do not implement ADR, although it is provided for in various professional service agreements.

\subsection{Subproblem 2}

Do architectural professionals discuss ADR prior to entering into an agreement with a client, or only once disputes arise? 
The questionnaire revealed that $69.4 \%$ of architectural professionals do not discuss ADR methods with their client prior to entering into an agreement. Comparative data done by the researcher also revealed that age, qualification and category of SACAP registration may also impact on the participant's response. Further cross-referenced data also revealed that participants who have been involved with disputes are more likely to discuss ADR with potential clients. Of all the required terms of confirming employment, the least likely item to be discussed is the provision for dispute resolution.

The researcher concludes that the majority of architectural professionals do not discuss ADR with their clients prior to entering into an agreement. This observation could indicate that a large number of professionals are in breach of the SACAP Code of Conduct, Rule 4.1. Not only will professionals be at risk of possible formal court proceedings, but they will also run the risk of losing their professional license.

\subsection{Subproblem 3}

Are architectural professionals informed about the different methods and benefits of ADR?

Data from the questionnaire indicates that $58.4 \%$ of the population have hardly any or no knowledge regarding the methods and benefits of ADR. This indicates that professionals have a misconception about the benefits and regulations of ADR. However, participants are able to identify some of the definitions of ADR provided.

The researcher concludes that the majority of architectural professionals are not informed about most of the matters, including the methods and benefits, of ADR, although it is provided for in many professional service agreements used in the built environment.

\section{Discussion and conclusion}

The study set out to establish the existing knowledge that architectural professionals in South Africa have about ADR methods. The SACAP Code of Conduct lists eight compulsory requirements in a written agreement. The article focused on the provision for dispute resolution and stated that ADR shall form part of a formal agreement between contracting parties.

The research has proved that architectural professionals have hardly any knowledge regarding ADR methods, specifically the implementation thereof. It is concerning that $69.4 \%$ of architectural 
professionals do not discuss ADR methods with their client prior to the commencement of a project. The significant impact of this article lies in the fact that this study reached out to all the possible architectural professionals in South Africa. Although previous studies have addressed the many causes and results of ADR, this study is unique, due to the fact that it specifically investigates the knowledge and implementation of ADR by architectural practitioners in South Africa. This is the first published evidence of many anecdotal statements on the lack of implementation and knowledge regarding ADR methods in the architectural profession of South Africa.

The following main issues were derived from the analytical survey:

- A large number of architectural professionals do not implement ADR, and

- $\quad$ A large number of architectural professionals are not familiar with the term ADR and its associated benefits.

The evidence indicates that a significant portion of architectural professionals are currently in breach of the SACAP Code of Conduct and could potentially lose their professional license. As a result, it is recommended that architectural professionals familiarise themselves with the SACAP Code of Conduct and other enforceable laws.

The researcher recommends that regulatory bodies, voluntary associations (VAs) and tertiary institutions urgently address these matters. It is recommended that regular workshops be held on this topic and that VAs communicate the relevant documents to their members electronically. These actions could be in the form of regulated enforcement and, therefore, educating potential architectural professionals in practice-specific matters.

Professionals should also familiarise themselves with the relevant professional service agreements that are available and that provide ADR methods as a means for resolving disputes. The built environment of South Africa makes provision for ADR methods in a variety of contracts such as the JBCC PBA (2007: 30-31), CIDB (2009: 12), FIDIC (2010: 65-70), PROCSA (2015: 11), and the SAIA CAA (2008: 3). Further investigation is necessary to establish the current implementation of ADR in professional service agreements and how to address this matter.

By creating awareness on the lack of knowledge regarding ADR and the benefits thereof, professionals are bound to familiarise themselves with this topic and discuss ADR methods with clients at the onset of a building project. This will make architectural professionals 
better informed and equipped when disputes arise within the built environment.

\section{References}

Barrett, J.T. \& Barret, J.P. 2004. A history of alternative dispute resolution: The story of a political, cultural, and social movement. San Francisco, California: Jossey-Bass.

Bollen, K., Euwema, M. \& Muller, P. 2010. Why are subordinates less satisfied with mediation? Negotiation Journal, 26(4), pp. 417-433. https://doi.org/10.1111/j.1571-9979.2010.00282.x

Botha, H. 2000. Conflict in the construction industry. London: Bellstone Training (International) Limited.

Boubala, H.G.O. 2010. Risk management of SMMEs. Unpublised M.Tech. thesis. Cape Town: Cape Peninsula University of Technology, Internal Auditing.

Bowling, A. 1997. Research methods in health. Buckingham: Open University Press.

Brown, H.J. \& Marriot, A.L. 1993. ADR principles and practice. London: Sweet \& Maxwell.

Burns, N. \& Grove, S.K. 1997. The practice of nursing research conduct, critique, and utilization. Philadelphia, Pennsylvania: W.B. Saunders and Co.

Bvumbwe, C. \& Thwala, D.W. 2011. An exploratory study of dispute resolution methods in the South African construction industry, Vol. 21. Singapore: IACSIT Press.

Chong, H. \& Zin, R.M. 2012. Selection of dispute resolution methods: Factor analysis approach. Engineering, Construction and Architectural Management, 19(4), pp. 428-443. https://doi. org/10.1108/09699981211237120

cidb (construction industry development board). 2009. Standard professionals service contract. $3^{\text {rd }}$ edition. Pretoria: cidb.

Courtright, C. 2007. Context in information behavior research. Annual Review of Information Science and Technology, 41 (1), pp. 273-306. https://doi.org/10.1002/aris.2007.1440410113

De Oliveira, M. 2012. Dispute resolution under the general conditions of contract 2010. Potchefstroom: North West University. 
Wilcocks \& Laubscher • Investigating alternative dispute-resolution ...

FIDIC (International Federation of Consulting Engineers). 2010. General conditions of contract. $2^{\text {nd }}$ ed. Geneva: SAICE.

Finsen, E. 1999. The building contract: A commentary on the JBCC agreements. Cape Town: Juta.

Finsen, E. 2005. The building contract: A commentary on the JBCC agreements. $2^{\text {nd }}$ ed. Cape Town: Juta.

Fisher, R.C., Ury, W.L. \& Patton, M.B. 1991. Getting to yes. London: Penguin.

Freyer, D.H. 1997. The American experience in the field of ADR. In: Rao, P.C. \& Sheffield, W. (Eds). Alternative dispute resolution: What it is and how it works. New Delhi: International Centre for Alternative Dispute Resolution, Delhi, Universal Law Publishing Company, pp. 108-122.

Goldberg, S.B., Sander, F.E.A. \& Rogers, N. 1992. Dispute resolution: Negotiation, mediation and other processes. Boston, Massachusetts: Little Brown and Company.

Hibberd, P. \& Newman, P. 2001. ADR and adjudication in construction disputes. London: Blackwell Science.

JBCC (Joint Building Contracts Committee). 2007. Principal building agreement. JBCC Series 2000, ed. 5.0. Johannesburg: JBCC.

Krejcie, R.V. \& Morgan, D.W. 1970. Determining sample size for research activities. Educational and Psychological Measurement, 30(3), pp. 607-610. https://doi.org/10.1177/001316447003000308

Leedy, P.D. \& Ormrod, J.E. 2005. Practical research: Planning and design. $8^{\text {th }}$ ed. Upper Saddle River, New Jersey: Prentice Hall.

Loots, P. 1991. Alternative methods of dispute resolution in the construction industry. SA Builder, May, pp. 8-13.

Maritz, M.J. 2007. An investigation into the adjudication of disputes in the South African construction industry. In: Proceedings of the Royal Institute of Chartered Surveyors Conference, 6-7 September 2007, Atlanta Georgia. Atlanta, Georgia: Institute of Technology, pp. 419-426.

Motiwal, O.P. 1998. Alternative dispute resolution in India. Journal of International Arbitration, 15(2), pp. 117-127.

Ntuli, N.N. 2013. Policy and government's role in constructive ADR developments in Africa. Presented at the conference: ADR and Arbitration in Africa, 28-29 November 2013, Cape Town, pp. 2-3. 
OED (Oxford English Dictionary). 2016. Oxford English Dictionary. 12 ${ }^{\text {th }}$ ed. [Edited by Judy Pearsall]. New York: Oxford University Press.

Pelser, A. 2013. Investigating the client-architect agreement as contracts of agency to determine the role and authority of the architectural professional. Unpublished M.Tech. dissertation. Pretoria: Tshwane University of Technology, Department of Architecture.

Povey, A. 2005. An investigation into the mediation of disputes in the South African construction industry. Journal of the South African Institution of Civil Engineering, 47(1), pp. 2-7.

Pretorius, P. 1990. ADR: A challenge to the bar for the 1990s. Consultus, 1, p. 38.

Pretorius, P. 1993. Dispute resolution. Cape Town: Juta.

PROCSA (Professional Consultants Services Agreement Committee). 2015. Professional client/consultant service agreement, ed. 3.2, October 2015. Pretoria: PROCSA.

Quail, G.P. 1978. The building contract. Pretoria: Building Publications. Ramsden, P. 2009. Law of arbitration. Cape Town: Juta.

Rao, P.C. 2009. Alternative to litigation in India. In: Rao, P.C. \& Sheffield, W. (Eds). Alternative dispute resolution 24. Delhi: Universal Law Publishing Company Pvt. Ltd.

SACAP (South African Council for the Architectural Profession). 2015. Annual report 2014/2015. Johannesburg: The South African Institute of Architects.

SAIA (The South African Institute of Architects). 2008. Client architect agreement 2008. Pretoria: SAIA.

SAIA (The South African Institute of Architects). 2014. About the institution. [Online]. Available at: <http://saia.org.za/?page_id=39> [Accessed: 14 April 2016].

South Africa. 1996. The Bill of Rights, Act 108 of 1996, Chapter 2. Pretoria: Government Printer. [Laws].

Stewart, W.J. 2006. Collins dictionary of law. [Online]. Available at: <http://legaldictionary.thefreedictionary.com/ alternative+dispute+resolution> [Accessed: 22 August 2016].

Struwig, F.W. \& Stead, G.B. 2001. Planning, designing and reporting research. Cape Town: Pearson Education South Africa. 
Wilcocks \& Laubscher • Investigating alternative dispute-resolution ...

Surveymonkey. 2016. About us. [Online]. Available at: <https://www. surveymonkey.com/mp/aboutus/> [Accessed: 28 November 2016].

Thumbiran, I. 2015 Summary: Prompt payment. Unpublished paper presented to adjudication delegates at the University of Pretoria.

Trollip, A.T 1991. Alternative dispute resolution in a contemporary South African context. Durban, South Africa: Butterworths.

Van Stade, B. \& Chiunda, M. 2016. (Chief operations managers at SACAP). Personal communication on the number of architectural professionals in South Africa. Pretoria. [3 November 2016].

Van Zyl, C.H., Verster, J.J.P. \& Ramabodu, M.S. 2010. Dispute resolution alternatives: Problems, preference and process. Paper delivered at the Construction, Building and Real Estate Research Conference (COBRA) of the Royal Institution of Chartered Surveyors (RICS), 2-3 September 2010, Université Paris-Dauphine.

Verster, J.J.P. 2006. Managing cost, contracts, communication and claims: A quantity surveying perspective on future opportunities. In: Proceedings of the $1^{\text {st }}$ ICEC \& IPMA Global Congress on Project Management, $5^{\text {th }}$ World Congress on Cost Engineering, Project Management and Quantity Surveying, 23-26 April 2006, Ljubljana, Slovenia, CD ROM.

Wang, M. 2000. Are alternative dispute methods superior to litigation in resolving disputes in international commerce? No. 2. Arbitration International. Chartered Institute of Arbitrators, 189.

Wilcocks, T. 2016. Investigating the use of alternative dispute resolution methods in the architectural profession of South Africa. Unpublished M.Tech. dissertation. Pretoria: Tshwane University of Technology, Architecture.

Williams, C. 2007. Research methods. Journal of Business and Economic Research. 5(3), pp. 65-72.

WIPO (World Intellectual Property Organization). 2012. Efficient resolution of disputes in R\&D collaborations, licensing and other technology transfer. [Online]. Available at: <http://www.wipo.int/ export/sites/www/amc/en/docs/ipr20121127.pdf> 22 August 2016].

[Accessed: 